\title{
PENGARUH PENGGANTIAN PENGGUNAAN JAGUNG KUNING DALAM RANSUM DENGAN CAMPURAN LIMBAH ROTI DAN TEPUNG JERAMI BAWANG PUTIH TERHADAP PENAMPILAN DAN JUMLAH LEMAK ABDOMEN ITIK BALI JANTAN
}

\author{
TRISNADEWI A. A. A. S., UTAMI I. A. P., ARYANI I G. A. I., \\ PARTAMA I. B. G., DAN BIDURA I G. N. G. \\ FAKULTAS PETERNAKAN UNIVERSITAS UDAYANA, DENPASAR \\ Jl. P.B Sudirman, Denpasar, Bali \\ Email: dewitrisna26@yahoo.com
}

\begin{abstract}
ABSTRAK
Penelitian ini bertujuan untuk mengetahui pengaruh penggunaan campuran limbah roti dan tepung jerami bawang putih sebagai pengganti jagung dalam ransum terhadap penampilan dan jumlah lemak abdomen itik bali jantan umur 2-8 minggu. Rancangan yang digunakan adalah Rancangan Acak Lengkap (RAL) dengan empat perlakuan dan enam kali ulangan. Tiap ulangan menggunakan lima ekor itik Bali jantan umur dua minggu dengan berat badan homogen. Ransum yang diberikan disusun dengan kandungan protein kasar 18\% dan energi termetabolis $2900 \mathrm{kkal} / \mathrm{kg}$ yang mengandung 50\% jagung kuning sebagai kontrol (A). Penggantian masing-masing: $30 \%, 60 \%$, dan 100\% penggunaan jagung kuning dalam ransum dengan campuran limbah roti dan tepung jerami bawang putih (LRBP), masing-masing sebagai perlakuan B, C, dan D. Ransum dan air minum diberikan secara ad libitum.Variabel yang diamati adalah konsumsi ransum, konsumsi zat makanan, berat badan akhir, pertambahan berat badan, Feed Conversion Ratio (FCR) dan lemak abdomen. Hasil penelitian menunjukkan bahwa konsumsi ransum, berat badan akhir, pertambahan berat badan dan efisiensi penggunaan ransum pada itik perlakuan $\mathrm{B}, \mathrm{C}$, dan $\mathrm{D}$ nyata $(\mathrm{P}<0,05)$ lebih tinggi daripada kontrol $(\mathrm{A})$. Akan tetapi jumlah lemak abdomen nyata $(\mathrm{P}<0,05)$ lebih rendah daripada kontrol. Dapat disimpulkan bahwa penggantian 100\% jagung kuning dalam ransum dengan campuran limbah roti dan tepung jerami bawang putih (LBRP) dapat meningkatkan penampilan dan menurunkan lemak abdomen itik bali jantan umur 2-8 minggu.
\end{abstract}

Kata kunci : limbah roti, fitokimia, penampilan, lemak abdomen

\begin{abstract}
THE IMPLEMENTATION OF BAKERY WASTE AND GARLIC STRAW MEAL MIXTURES AS YELLOW CORN SUBSTITUTION IN DIETS FOR IMPROVING ABDOMINAL-FAT AND PERFORMANCE OF MALE BALI DUCKLING
\end{abstract}

\begin{abstract}
The study was carried out to determine effect of bakery waste and garlic straw meal mixtures in diets as yellow corn substitution for improving abdominal fat and performance of male Bali duckling from 2 up to 8 weeks of age at Tabanan, Bali. Those male Bali ducklings were assigned to 4 treatments with 6 replications in a Completely Randomized Design (CRD). Each treatment consists of 5 male Bali ducklings with homogenous body weight. The diets fed were formulated with $18 \%$ crude protein an $2900 \mathrm{kcal} \mathrm{ME} / \mathrm{kg}$. The treatments were (A) $50 \%$ yellow corn as control diet; 30\% (B), 60 (C), and 100\% (D) substitution of yellow corn implementation in diets with bakery waste and garlic straw meal mixtures, respectively. Diets and water were given in ad libitum. The variables observed were feed and water consumption, final body weight gain, Feed Conversion Ratio (FCR), and abdominal-fat. The study showed that feed and water consumption, final body weight gain and feed efficiency in treatment B, C, and D were significantly higher than control diet $(\mathrm{P}<0.05)$. In contrast, abdominal-fat was significantly lower than control diet $(\mathrm{P}<0.05)$. It can be concluded that $100 \%$ yellow corn substitution in diets with bakery waste and garlic straw meal mixtures could increase performance but decrease abdominal-fat of male Bali ducklings.
\end{abstract}

Keywords: bakery waste, phytochemical, performance, abdominal-fat 


\section{PENDAHULUAN}

Penggunaan jagung kuning dalam penyusunan ransum unggas dapat mencapai 40-70\% dari total ransum. Disamping sebagai pakan ternak, jagung juga dikonsumsi manusia dan bahan baku industri sehingga fluktuasi harga jagung akan besar. Hal ini tentunya akan berpengaruh terhadap harga ransum yang mencapai 60-70\% dari total biaya produksi.

Melihat kenyataan tersebut, maka perlu alternatif lain untuk mengurangi atau mengganti penggunaan jagung dalam ransum. Alternatif yang mungkin dapat dilakukan adalah pemanfaatan limbah roti yang dikombinasikan dengan tepung jerami bawang putih (Allium sativum).

Limbah roti merupakan sisa pembuatan roti atau roti yang sudah kadaluarsa yang dikembalikan oleh pedagang ke perusahaan pembuat roti. Hasil penelitian pendahuluan menunjukkan bahwa komposisi zat-zat makanan pada limbah roti hampir menyerupai jagung kuning yaitu mengandung 14,35\% protein kasar; 16,25\% lemak kasar; 0,91\% serat kasar; 0.07\% Ca; 022\% P; dan energi metabolis $3294 \mathrm{kkal} / \mathrm{kg}$ (Sudiastra dan Suasta, 1997).

Jerami bawang putih umunya dibakar atau dibiarkan begitu saja sebagai mulsa oleh petani. Ketersediaannya cukup banyak dan dari beberapa penelitian menunjukkan bahwa daun bawang putih mengandung senyawa kimia fitokimia allyl sulfide yang mempunyai khasiat faali luarbiasa, diantaranya sebagai antimikrobia, antiinflamasi, merangsang sistem imun, dan mampu menurunkan kadar kolesterol (Karyadi, 1997). Penggunaan sampai tingkat $7 \%$ dalam ransum ternyata mampu meningkatkan produksi telur, meningkatkan efisiensi penggunaan ransum, meningkatkan warna kuning telur, dan menurunkan kadar kolesterol telur ayam (Bidura dan Suwidjayana, 1997). Dilaporkan juga bahwa kandungan serat kasar yang tinggi pada jerami bawang putih $(46,92 \%)$ akan sangat baik bila dikombinasikan dengan limbah roti yang kandungan serat kasarnya rendah (o,60\%). Disamping itu, adanya khasiat fitokimia jerami bawang putih yang dapat meningkatkan warna daging sehingga akan dapat menggantikan kedudukan zat warna xantophyl pada jagung kuning.

Kombinasi antara limbah roti dan tepung jerami bawang putih akan dapat kiranya mengganti jagung dalam ransum tanpa berpengaruh buruk terhadap penampilan. Namun perlu penelitian lebih lanjut sampai level berapa penggantian tersebut.

\section{MATERI DAN METODE}

\section{Tempat dan Lama Penelitian}

Penelitian dilaksanakan di kandang milik peternak di desa Dajan Peken, Kecamatan Tabanan, Kabupaten Tabanan, dan berlangsung selama enam minggu.

\section{Kandang dan Itik}

Kandang yang digunakan adalah kandang dengan sistem battery colony dari bilah bambu sebanyak 24 buah. Masing-masing petak kandang berukuran panjang 1,0 m; lebar 0,5 $\mathrm{m}$ dan tinggi $0,4 \mathrm{~m}$. Semua petak kandang terletak dalam sebuah bangunan kandang dengan atap genteng. Tiap petak kandang dilengkapi dengan tempat pakan dan air minum.

Itik yang digunakan adalah itik Bali jantan umur dua minggu dengan berat badan homogen. Itik diperoleh dari petani peternak itik di daerah Tabanan.

\section{Ransum dan Air Minum}

Ransum yang digunakan dalam penelitian dihitung berdasarkan tabel komposisi zat makanan menurut Scott et al. (1982), dengan menggunakan bahan seperti: jagung kuning, tepung ikan, bungkil kelapa, kacang kedelai, garam, premix, limbah roti, dan tepung jerami bawang putih. Semua ransum perlakuan disusun isokalori (ME : $2900 \mathrm{kkal} / \mathrm{kg}$ ) dan isoprotein (CP: 18\%). Komposisi bahan dan zat makanan dalam ransum penelitian tersaji pada Tabel 1 dan 2. Air minum yang diberikan bersumber dari PDAM setempat.

\section{Tepung Jerami Bawang Putih (Allium sativum)}

Jerami bawang putih berasal dari bawang putih (Allium sativum) lokal yang sudah kering. Sebelum digunakan, terlebih dahulu jerami bawang putih dikering mataharikan, kemudian direcah yang selanjutnya disaring dengan saringan tepung berdiameter 1-2 $\mathrm{mm}$.

\begin{tabular}{|c|c|c|c|c|c|}
\hline \multirow[b]{2}{*}{ Bahan } & \multicolumn{4}{|c|}{ Perlakuan } & \multirow{2}{*}{$\begin{array}{c}\text { Roti + } \\
\text { Bawang } \\
\text { Putih }\end{array}$} \\
\hline & A & B & C & $\mathrm{D}$ & \\
\hline Jagung kuning & 50,00 & 35,00 & 20,00 & 0,00 & - \\
\hline Tepung ikan & 11,20 & 12,00 & 12,00 & 12.00 & - \\
\hline Bungkil kelapa & 14,76 & 14,76 & 14,76 & 14,76 & - \\
\hline Dedak padi & 14,87 & 14,17 & 14,17 & 14,17 & - \\
\hline Kacang kedelai & 6,28 & 6,28 & 6,28 & 6,28 & - \\
\hline Minyak kelapa & 2,29 & 2,29 & 2,29 & 2,29 & - \\
\hline $\mathrm{NaCl}$ & 0,20 & 0,20 & 0,20 & 0,20 & - \\
\hline Mineral mix & 0,40 & 0,30 & 0,30 & 0,30 & - \\
\hline $\begin{array}{l}\text { Campuran limbah roti dengan } \\
\text { tepung jerami bawang putih }\end{array}$ & - & 15,00 & 30,00 & 50,00 & - \\
\hline Limbah roti & - & - & - & - & 80,00 \\
\hline Tepung jerami bawang putih & - & - & - & - & 20,00 \\
\hline Total & 100,00 & 100,00 & 100,00 & 100,00 & 100,00 \\
\hline
\end{tabular}

Keterangan: Ransum basal dengan menggunakan $50 \%$ jagung kuning sebagai kontro (A), penggantian masing-masing: 30\% jagung kuning (B), $60 \%$ (C), $100 \%$ (D) dengan campuran limbah roti dan tepung jerami bawang putih.

\section{Limbah Roti}

Limbah roti diperoleh dari perusahaan roti di daerah kabupaten Badung dan kota Denpasar. Limbah roti yang dimaksud adalah limbah dari pabrik pembuatan roti serta roti rusak dan kadaluarsa. 


\section{Rancangan Percobaan}

Rancangan yang digunakan dalam penelitian ini adalah Rancangan Acak Lengkap (RAL) dengan empat perlakuan dan enam kali ulangan. Tiap ulangan (unit percobaan) menggunakan lima ekor itik bali jantan umur dua minggu dengan berat badan homogen. Keempat perlakuan tersebut adalah:

- Ransum basal dengan menggunakan 50\% jagung kuning sebagai kontrol (A)

- Penggantian 30\% jagung kuning dengan campuran limbah roti dengan tepung jerami bawang putih (B)

- Penggantian 60\% jagung kuning dengan campuran limbah roti dengan tepung jerami bawang putih (C)

- Penggantian 100\% jagung kuning dengan campuran limbah roti dengan tepung jerami bawang putih (D)

\section{Pemberian Ransum dan Air minum}

Ransum dan air minum diberikan ad libitum. Penambahan ransum dilakukan 2-3 kali sehari dan diusahakan tempat ransum terisi $3 / 4$ bagian untuk mencegah agar ransum tidak tercecer. Pemberian air minum dilakukan setiap hari.

Tabel 2. Komposisi Zat Makanan dalam Ransum Itik Bali Jantan Umur 2-8 minggu

\begin{tabular}{|c|c|c|c|c|c|c|}
\hline \multirow[b]{2}{*}{ Komposisi kimia } & \multirow[b]{2}{*}{ Satuan } & \multicolumn{4}{|c|}{ Perlakuan } & \multirow{2}{*}{$\begin{array}{c}\text { Campuran } \\
\text { Roti + } \\
\text { Bawang } \\
\text { Putih }\end{array}$} \\
\hline & & A & B & C & D & \\
\hline Energi metabolis & kkal/kg & 2900 & 2872 & 2815 & 2739 & 2992 \\
\hline Protein kasar & $\%$ & 18,00 & 19,17 & 19,82 & 20,68 & 12,89 \\
\hline Lemak kasar & $\%$ & 7,71 & 9,06 & 10,41 & 12,21 & 12,90 \\
\hline Serat kasar & $\%$ & 4,33 & 5,85 & 7,36 & 9,39 & 12,11 \\
\hline Kalsium & $\%$ & 3,82 & 3,83 & 3,83 & 3,84 & 0,06 \\
\hline Fosfor tersedia & $\%$ & 0,60 & 0,61 & 0,62 & 0,64 & 0,18 \\
\hline Arginin & $\%$ & 1,33 & 1,28 & 1,21 & 1,14 & 0,11 \\
\hline Sistin & $\%$ & 0,32 & 1,29 & 0,27 & 0,23 & 0,01 \\
\hline Glisin & $\%$ & 0,66 & 0,61 & 0,56 & 0,50 & 0,07 \\
\hline Histidin & $\%$ & 0,44 & 0,41 & 0,38 & 0,34 & - \\
\hline Isoleusin & $\%$ & 0,84 & 0,79 & 0,75 & 0,69 & 0,09 \\
\hline Leusin & $\%$ & 1,60 & 1,45 & 1,30 & 1,10 & 0.10 \\
\hline Lysin & $\%$ & 1,19 & 1,17 & 1,14 & 1,07 & 0,04 \\
\hline Methionin & $\%$ & 0,40 & 0,39 & 0,39 & 0,38 & 0,13 \\
\hline Penilalanin & $\%$ & 0,84 & 0,78 & 0,72 & 0,65 & 0,11 \\
\hline Tyrosin & $\%$ & 0,63 & 0,57 & 0,51 & 0,43 & 0,02 \\
\hline
\end{tabular}

Keterangan: Ransum basal dengan menggunakan $50 \%$ jagung kuning sebagai kontrol (A), penggantian masing-masing: $30 \%$ jagung kuning (B), $60 \%$ (C), $100 \%$ (D) dengan campuran limbah roti dan tepung jerami bawang putih.

\section{Variabel yang Diamati}

1. Konsumsi ransum dan air minum yaitu selisih antara jumlah ransum dan air yang diberikan dengan sisa ransum dan air. Konsumsi ransum diukur setiap minggu.

2.Pertambahan berat badan; diperoleh dengan mengurangi berat badan akhir dengan berat badan minggu sebelumnya. Sebelum penimbangan terlebih dahulu itik dipuasakan selama kurang lebih 12 jam.

3.Feed Conversion Ratio (FCR); merupakan perbandingan antara jumlah ransum yang dikonsumsi dengan pertambahan berat badan. FCR merupakan tolok ukur untuk menilai tingkat efisiensi penggunaan ransum. Semakin rendah nilai FCR, semakin tinggi efisiensi penggunaan ransum, demikian juga sebaliknya.

4.Perlemakan tubuh itik menurut Kubena et al. (1974) adalah: pad fat (dipisahkan pertautannya dari usus), lemak empedal (dipisahkan dari empedal), dan abdominal fat (gabungan pad fat, mecenteric fat dan lemak empedal).

\section{Analisis Statistika}

Data yang diperoleh dianalisis dengan sidik ragam dan apabila terdapat perbedaan yang nyata $(\mathrm{P}<0,05)$ diantara perlakuan, maka dilanjutkan dengan uji jarak berganda dari Duncan (Steel and Torrie, 1989).

\section{HASIL DAN PEMBAHASAN}

Rataan jumlah ransum yang dikonsumsi selama enam minggu penelitian pada itik yang diberi ransum kontrol (A) adalah 6218,37\% g/ekor/6 minggu (Tabel 3). Penggantian $30 \%$ jagung kuning dengan campuran limbah roti dengan tepung jerami bawang putih (B), penggantian $60 \%$ jagung kuning dengan campuran limbah roti dengan tepung jerami bawang putih (C), dan penggantian $100 \%$ jagung kuning dengan campuran limbah roti dengan tepung jerami bawang putih (D), menyebakan konsumsi ransum meningkat masing-masing: 6,29\%, 8,08\%, dan 8,437\% lebih tinggi daripada kontrol dan secara statistik berbeda nyata $(\mathrm{P}<0,05)$. Terjadi peningkatan konsumsi ransum dan zat makanan lainnya dengan adanya penggunaan campuran limbah roti dengan tepung jerami bawang putih sebagai pengganti penggunaan jagung kuning dalam ransum. Hal ini disebabkan karena menurunnya kandungan energi termetabolis ransum sebagai akibat penggantian jagung kuning dengan campuran limbah roti dengan tepung jerami bawang putih. Itik akan berusaha mengkonsumsi ransum untuk memenuhi kebutuhan energi. Menurut Wahyu (1988), ternak unggas umumnya mengkonsumsi ransum untuk memenuhi kebutuhan akan energi. Konsumsi ransum akan meningkat apabila kandungan energi ransum menurun. Disamping itu, peningkatan konsumsi ransum tersebut disebabkan juga oleh adanya senyawa fitokimia dan serat kasar yang tinggi pada tepung jerami bawang putih. Senyawa fitokimia dapat menghambat pertumbuhan mikroorganisme yang merugikan dalam saluran pencernaan 
itik, sehingga pemanfaatan zat makanan oleh itik dapat optimal dan pertumbuhan akan meningkat. Menurut Block (1985), senyawa aktif yang dapat diekstrak dari bawang putih adalah: allicin, skordinin, allyl, dan diallyl sulfida yang mampu menghambat pertumbuhan beberapa jenis mikroba. Hasil penelitian ini didukung oleh Bidura (1999) yang mendapatkan bahwa penggunaan tepung daun bawang putih dalam ransum nyata meningkatkan konsumsi ransum dan protein.

Meningkatnya konsumsi ransum sebagai konsekuensi logis akan meningkat pula konsumsi zat makanan lainnya, seperti protein dan asam amino lysin. Selain hal tersebut, penggunaan campuran limbah roti dan tepung jerami bawang putih dalam ransum menyebabkan peningkatan kandungan serat kasar ransum (Tabel 2). Peningkatan kandungan serat kasar tersebut menyebabkan laju aliran ransum dalam saluran pencernaan meningkat. Serat kasar ransum yang tinggi menyebabkan ada sebagian fraksi energi netto yang hilang untuk aktivitas tambahan gizard, serta untuk gerak peristaltik usus untuk mendorong serat kasar keluar saluran pencernaan (Lloyd et al., 1978), sebagai akibatnya itik akan meningkatkan konsumsi ransum untuk pemenuhan energi.

Jumlah air minum yang dikonsumsi oleh itik kontrol adalah 19,09 l/ekor/6 minggu (Tabel 3). Terjadi peningkatan konsumsi air minum secara nyata ( $\mathrm{P}<0,05)$ pada itik perlakuan $\mathrm{B}, \mathrm{C}$, dan $\mathrm{D}$ masing-masing: $19,07 \%, 20,22 \%$, dan 25,98\% lebih tinggi daripada kontrol. Konsumsi air minum yang meningkat sebagai akibat peningkatan konsumsi ransum yang digunakan untuk pelarutan pakan di dalam saluran pencernaan itik. Sesuai dengan pendapat Wahyu (1988), umumnya konsumsi ransum berbanding lurus dengan konsumsi air. Hasil penelitian ini didukung oleh Bidura et al. (1997) bahwa penggunaan serbuk gergaji kayu sebagai sumber serat kasar dalam ransum, nyata meningkatkan konsumsi ransum dan air minum.

Rataan pertambahan berat badan itik kontrol selama enam minggu penelitian adalah 853,36 g/ekor/6 minggu (Tabel 3). Pertambahan berat badan itik perlakuan B, C, dan D secara berurutan adalah 11,45\%, 15,37\%, dan $16,45 \%$ nyata $(\mathrm{P}<0,05)$ lebih tinggi daripada itik kontrol. Penggunaan campuran limbah roti dan tepung jerami bawang putih sebagi pengganti jagung kuning dalam ransum secara nyata meningkatkan pertambahan berat badan dan efisiensi penggunaan ransum itik. Meningkatnya berat badan tersebut disebabkan karena adanya senyawa fitokimia pada bahan tersebut. Pada daun bawang putih senyawa allinase akan memicu perubahan komponen prekursor menjadi komponen sulfur dan hal inilah yang kemudian dilaporkan berkhasiat memacu pertumbuhan (Wijaya, 1997). Pertambahan berat badan yang semakin meningkat juga disebabkan
Tabel 3. Pengaruh Penggantian Jagung Kuning dalam Ransum dengan Campuran Limbah Roti dan Tepung Jerami Bawang Putih (LRBP) terhadap Penampilan Itik Bali Jantan Umur 2-8 minggu

\begin{tabular}{|c|c|c|c|c|c|}
\hline \multirow{2}{*}{ Variabel } & \multicolumn{4}{|c|}{ Perlakuan $^{1)}$} & \multirow{2}{*}{ SEM $^{2)}$} \\
\hline & $A$ & $\mathrm{~B}$ & $\mathrm{C}$ & $\mathrm{D}$ & \\
\hline Berat badan akhir (g) & $1106,27 b$ & $1203,92 a$ & $1238,20 a$ & $1245,81 a$ & 25,730 \\
\hline $\begin{array}{l}\text { Pertambahan berat } \\
\text { badan (g/ekor/6 } \\
\text { minggu) }\end{array}$ & $853,36 b$ & $951,05 a$ & $984,49 a$ & $993,72 a$ & 23,92 \\
\hline $\begin{array}{l}\text { Konsumsi ransum (g/ } \\
\text { ekor/6 minggu) }\end{array}$ & $6218,37 b$ & $6609,47 a$ & $6720,71 a$ & $6742,47 a$ & 82,097 \\
\hline $\begin{array}{l}\text { Konsumsi air (l/ekor/6 } \\
\text { minggu) }\end{array}$ & $19,09 b$ & $22,73 a$ & $22,95 a$ & $24,05 a$ & 0,871 \\
\hline $\begin{array}{l}\text { Konsumsi protein (g/ } \\
\text { ekor/6 minggu) }\end{array}$ & $1119,31 a$ & $1267,04 b$ & $1332,04 c$ & $1394,34 c$ & 32,947 \\
\hline $\begin{array}{l}\text { Konsumsi lysin (g/ } \\
\text { ekor/6 minggu) }\end{array}$ & $73,99 a$ & 77,33a & $76,62 a$ & $72,14 a$ & 3,402 \\
\hline $\begin{array}{l}\text { Feed Conversion Ratio } \\
\text { (FCR) }\end{array}$ & $7,29 a$ & $6,95 a$ & $6,83 a$ & $6,79 a$ & 0,106 \\
\hline $\begin{array}{l}\text { Abdominal-fat ( } \% \\
\text { berat hidup) }\end{array}$ & $2,61 a$ & $2,56 a$ & $2,37 b$ & $2,39 \mathrm{~b}$ & 0,041 \\
\hline
\end{tabular}

Keterangan:

1. Ransum basal dengan menggunakan $50 \%$ jagung kuning sebagai kontrol (A), penggantian $30 \%$ jagung kuning dengan campuran limbah roti dengan tepung jerami bawang putih (B), penggantian $60 \%$ jagung kuning dengan campuran limbah roti dengan tepung jerami bawang putih (C), penggantian $100 \%$ jagung kuning dengan campuran limbah roti dengan tepung jerami bawang putih (D)

2. Standard Error of the Treatment Means

3. Nilai dengan huruf yang sama pada baris yang sama menunjukkan berbeda tidak nyata $(P>0,05)$

karena peningkatan konsumsi protein. Protein sangat diperlukan sekali untuk pertumbuhan itik (Wahyu, 1988). Menurut Sugahara dan Kubo (1992), konsumsi protein dan asam amino metionin yang tinggi dapat meningkatkan retensi energi sebagai protein dalam tubuh. Komponen bersulfur pada bawang putih akan meningkatkan ketersediaan asam amino yang mengandung sulfur seperti metionin dalam tubuh itik. Menurut Seaton et al. (1978), meningkatnya konsentrasi asam amino metionin dalam tubuh dapat menghasilkan enzim penangkal racun, merangsang sistem kekebalan, mencegah penggumpalan trombosit, meningkatkan metabolisme hormon, peningkatan zat karsinogen dalam usus, efek antibakteri, dan antioksidan (Bidura, 2007) yang semuanya akan berdampak pada peningkatan pertumbuhan itik.

Rataan persentase lemak bantalan (abdominal-fat) pada itik kontrol adalah 2,61\% berat badan (Tabel 3) dan tidak menunjukkan adanya perbedaan yang nyata $(\mathrm{P}>0,05)$ dengan itik perlakuan B. Sedangkan persentase abdominal-fat pada itik perlakuan $\mathrm{C}$ dan $\mathrm{D}$ masingmasing: $19,20 \%$ dan $8,43 \%$ nyata $(\mathrm{P}<0,05)$ lebih rendah daripada kontrol. Jumlah lemak abdomen dalam tubuh itik menurun dengan adanya campuran limbah roti dan tepung jerami bawang putih dalam ransum. Penurunan ini sebagai akibat peningkatan konsumsi protein dan asam amino lysin. Seperti dilaporkan oleh Al-Batshan dan Hussein (1999), meningkatnya konsumsi protein secara nyata meningkatkan berat karkas, persentase karkas, dan persentase daging dada (breast meat) dan nyata menurunkan lemak abdomen (abdominal fat). 
Penurunan lemak abdomen tersebut dapat juga disebabkan karena saponin pada daun bawang putih dapat mengikat garam empedu endogenous (endogenous bile cholesterol). Saponin menurunkan kadar lipida dan kadar kolesterol darah dengan jalan menghambat aktivitas enzim pankreas dan metabolitnya, serta membentuk senyawa kompleks yang tidak larut dengan Zn (Ferket dan Middelton, 1999). Dilaporkan juga oleh Wibowo (1990) bahwa kerja scordinin pada bawang putih ternayata sama dengan enzim oksido-reduktase. Scordinin berfungsi sebagai enzim pendorong pertumbuhan yang efektif pada ternak. Hal ini telah dibuktikan pada tikus dan kelinci, ternyata scordinin mampu menekan kandungan lipida dan kolesterol dalam darah kelinci. Garam empedu sangat dibutuhkan sekali untuk mengemulsi lemak yang akan dimakan sehingga bisa dicerna oleh enzim lipase (Siregar et al., 1982).

Menurut Seaton et al. (1978) meningkatnya konsentrasi asam amino metionin dalam tubuh akan menurunkan deposisi lemak dalam tubuh. Augusti (1977) menyatakan bahwa pengaruh bawang putih terhadap lipida darah kemungkinanan disebabkan oleh senyawa yang mengandung sulfur yang terdapat di dalamnya, seperti alicin yang kadarnya memang tinggi pada bawang putih. Senyawa ini termasuk disulfida oksid tak jenuh. Rantai samping dari allyl tak jenuh ini mudah direduksi menjadi rantai propyl jenuh dan proses reduksi ini mengakibatkan penurunan reduced $N A D$ dan NADP dalam tubuh. Selain itu alicin juga mampu berikatan dengan gugus $-\mathrm{SH}$ yang merupakan bagian fungsional dari Co-A dalam proses pembentukan kolesterol tubuh.

Dari hasil penelitian dapat disimpulkan bahwa penggantian penggunaan jagung kuning dengan campuran limbah roti dan tepung jerami bawang putih (80:20) dapat meningkatkan pertambahan berat badan dan efisiensi penggunaan ransum, sebaliknya menurunkan jumlah lemak abdomen itik bali jantan umur 2-8 minggu.

\section{UCAPAN TERIMAKASIH}

Penulis mengucapkan terimakasih kepada Dirjen Dikti atas dana yang diberikan melalui dana Proyek Penelitian Dosen Muda sehingga penelitian dan penyusunan tulisan ilmiah ini dapat terlaksana. Ucapan terimakasih penulis sampaikan pula kepada Bapak I Gusti Ketut Astika atas peminjaman kandang dan kerjasamanya selama penelitian.

\section{DAFTAR PUSTAKA}

Al-Batshan, H. A., dan E. O. S. Hussein. 1999. Performance and Carcass Compsition of Broiler under Heat Sress: 1. The Effect of Dietary Energy and Protein. Asian-Aus. $J$. Anim. Sci. 12 (6): 914-922.

Augusti, K. T. 1977. Hypocolesteolsterolemic Effect of Garlic (Allium sativum). 211-214. Linn. Indian. J. Axp. Biol. 15: 489-490.

Bidura, I G. N. G, dan I N. Suwidjayana. 1997. Pemanfaatan Tepung Daun Bawang Putih (Allium sativum) dan Serbu Gergaji Kayu dalam Ransum terhadap Produksi dan Kadar Kolesterol Telur Ayam. Laporan Penelitian. Fakultas Peternakan Universitas Udayana Denpasar.

Bidura, I G. N. G. 1999. Penggunaan Tepung Jerami Bawang Putih (Allium sativum) dalam Ransum terhadap Penampilan Itik Bali. Majalah Ilmiah Peternakan. Fapet Unud No. 2 Vol. 2: 48-53

Bidura, I G. N. G. 2007. Aplikasi Produk Bioteknologi Pakan Ternak. UPT Penerbit Universitas Udayana, Denpasar.

Block, E. 1985. The Chemistry of Garlic and Onion. Scientific America 252: 94-100.

Ferket, P. R., and T. Middelton. 1999. Antinutritivein Feedstuff. Poultry International, March, 1999. 38(3): 46-55.

Karyadi, E. 1997. Khasiat Fitokimia bagi Kesehatan. Harian Kompas Minggu 20 Juli 1997 hal: 15 kolom: 1-7. PT. Gramedi. Jakarta.

Kubena, L. F., J. W. Deaton, F. C. Chen, and F. N. Reece. 1974. Factors Influencing the Quality of Abdominal Fat in Broilers. 2. Cage versus Floor Rearing. Poultry Sci. 53: 574-576.

Lloyd, I. E., B. E. McDonald, and E. W. Crampton. 1978. The Carbohydrate and Their Metabolism, In: Fundamental of Nutrition. 2nd Ed. W. H. Freman and Co. San Fansisco.

Scott, M. L., M. C. Nesheim, amd R. J. Young. 1982. Nutrition if the Chicken. 2nd Ed. M. L. Scott and Assoc. Ithaca.

Seaton, K. W., O. P. Thomas, R. M. Gous, and E. H. Bossard. 1978. The Effect of Diet on Liver Glycon and Body Composition in the Chick. Poultry Sci. 57: 692-697.

Siregar, A. P., K. B. Cumming and D. J. Farrel. 1982. The Nutrition of Meat. Type Duck II. The Effect of Fibri on Biological Performance and Carcass Characteristic. Aust. J. Agric. Res.: 3: 877-886.

Steel, R. G. D and J. H. Torrie. 1989. Principles and Procedure of Statistics. McGraw Hill Book Co. Inc. New York.

Sudiastra, I W. dan I M. Suasta. 1997. Pemanfaatan Limbah Roti untuk Makanan Ternak Babi. Laporan Penelitian Dosen Muda. Fakultas Peternakan Universitas Udayana Denpasar.

Sugahara, K., and T. Kubo. 1992. Involvement of Food Intake in the Decreased Energy Retention by Single Deficiencies of Lysine and Sulphur Containg Amino Acid in Growing Chicks. Brit. Poultry Sci. 33: 805-814.

Wahyu 1988. Ilmu Nutrisi Unggas. Gadjah Mada University Press. Yogyakarta.

Wijaya, C. H. 1997. Mengoptimalkan Khasiat Bawang. Harian Kompas Minggu 25 Mei 1997 hal: 15 kolom 6-9. PT. Gramedia. Jakarta. 